\title{
Sistem Informasi Geografis Pemanfaatan Aset Tanah Daerah Di Dinas Perumahan Dan Pemukiman Kabupaten Purbalingga
}

\author{
Toni Anwar ${ }^{1}$, Jeffri Prayitno Bangkit ${ }^{2}$, Andri Laksono ${ }^{3}$ \\ ${ }^{1,2,3}$ Universitas AMIKOM Purwokerto \\ E-Mail: ${ }^{1}$ Toni@amikompurwokerto.ac.id, ${ }^{2}$ Prayitnojeffry@amikompurwokerto.ac.id \\ ${ }^{3}$ Andrilaksono222@gmail.com
}

\begin{abstract}
ABSTRAK
Pemerintah dapat meningkatkan efektivitas operasi administratif dengan bantuan TIK. E-Government dianggap memberikan cara bagi pemerintah untuk melakukan inovasi kegiatan operasional untuk melayani masyarakat dengan lebih kompeten. Kabupaten Purbalingga memiliki aset tanah yang diperbolehkan untuk dimanfaatkan oleh OPD (Organisasi Perangkat Daerah) dan masyarakat umum. Masyarakat umum banyak yang belum mengetahui bahwa asset tanah tersebut boleh di manfaatkan dan letak asset-aset tanah tersebut hanya bisa dilihat di Kantor Dinas Perumahan dan Pemukiman. Permasalahan selanjutnya adalah prosedur dalam pengajuan pemanfaatan tanah yang terdiri dari beberapa tahap pengajuan berkas dan waktu tunggu untuk verifikasi data yang lama. Penelitian ini bertujuan untuk membuat Sistem Informasi Geografis (GIS) berbasia website dan android. Permasalahan prosedur pemanfaatan aset tanah yang mempunyai beberapa tingkatan merupakan kenadala yang umum di lingkungan pemerintahan. Framework yang diguanakan dalam pembuatan Scrum. Tahapan yang terdapat pada framework scrum adalah analisis situasi yang berlangsung di objek penelitian Tahap selanjutnya adalah pelaksaan pengembangan sistem informasi geografis yang terdiri dari, Analisis kebutuhan, Product Backlog dan proses Sprint sampai semua product backlog sudah selesai. Hasil penelitian ini adalah Sistem Informasi Geografis Pemanfaatan Aset Tanah Daerah yang dapat membantu pihak Dinas Perumahan dan Pemukiman dalam mensosialisasi, memfasilitasi dan mempermudah proses penyewaan aset tanah daerah.
\end{abstract}

Kata Kunci: E-Goverment, Scrum, Sistem Informasi Geografis, Android, Website.

\begin{abstract}
The government can increase the effectiveness of administrative operations with the help of ICTs. E-Government is considered to provide a way for the government to innovate operational activities to serve the community more competently. Purbalingga Regency has land assets that are allowed to be utilized by the Regional Government Organization $(O P D)$ and the general public. Many general public do not yet know that the assets of the land can be utilized and the location of the land assets can only be seen at the Office of Housing and Settlements. The next problem is the procedure for submitting land use which consists of several stages of filing files and waiting times for verification of long data. This study aims to create a Geographic Information System (GIS) with a website and android basis. Problems with procedures for utilizing land assets that have several levels are common conditions in the government environment. Framework used in making Scrum. The results of this study are the Geographic Information System for the Utilization of Regional Land Assets that can help the Department of Housing and Settlements in socializing, facilitating and facilitating the process of leasing regional land assets.
\end{abstract}

Keywords: E-Government, Scrum, Geographic Information Systems, Android, Website.

Author Korespondensi (Toni Anwar)

Email :Toni@amikompurwokerto.ac.id

\section{PENDAHULUAN}

Pemerintah berinvestasi pada implementasi $e$ government untuk memajukan layanan kepada masyarakat. Pemerintah dapat meningkatkan efektivitas operasi mereka dan dapat menjalankan operasi administratif mereka secara efisien dengan bantuan TIK. E-Government dianggap memberikan cara bagi pemerintah untuk melakukan inovasi kegiatan operasional untuk melayani masyarakat dengan lebih kompeten. Dengan peningkatan Teknologi Informasi dan Komunikasi (TIK), sekarang saatnya untuk memberikan akses elektronik ke fasilitas pemerintah kepada warga yang berada di berbagai tempat [1].

Kabupaten Purbalingga memiliki aset tanah yang diperbolehkan untuk dimanfaatkan oleh OPD 
(Organisasi Perangkat Daerah) dan masyarakat umum. Pemanfaatan aset tanah diperbolehkan dan tercantum dalam Peraturan Menteri Dalam Negeri Republik Indonesia Nomor 19 Tahun 2016 dan Peraturan Daerah Kabupaten Purbalingga Nomor 2 Tahun 2015. Masyarakat umum banyak yang belum mengetahui bahwa aset tanah tersebut boleh di manfaatkan dan letak aset-aset tanah tersebut hanya bisa dilihat di Dinas Perumahan dan Pemukiman. Permasalahan selanjutnya adalah prosedur dalam pengajuan pemanfaatan tanah yang terdiri dari beberapa tahap pengajuan berkas dan waktu tunggu untuk verifikasi data yang lama. Bahkan di tahun 2017 ada OPD yang memanfaatkan akses tanah tanpa mengikuti prosedur sehingga tergolong ilegal karena ketidak tahuan tentang prosedur pemanfaatan tanah. Permasalahan dalam sosialisasi kepada masyarakat adalah memberikan akses informasi secara luas kepada masyarakat dalam menggunakan teknologi. Teknologi yang tepat adalah web dan aplikasi mobile berbasis android yang saling terintegrasi dalam Sistem Informasi Geografis (GIS) [2]. Layanan terbuka dari pemerintahan dapat didukung dengan Penggunaan Sistem Informasi Geografis (GIS) data, dan informasi yang diperoleh dari GIS, dapat disampaikan lebih cepat [3].

Penentuan lokasi dengan menggunakan Sistem Informasi Geografis dapat menghemat waktu pencarian lokasi [4]. Pemetaan tanah aset pemerintah dengan menggunakan GIS sebagai basisdata dapat memberikan hasil yang baik untuk inventarisasi awal dan sangat membantu serta memudahkan dalam pengenalan maupun pengelolaan tanah aset pemerintah kota lebih lengkap dan terpadu lebih lanjut. [5] dan dalam jangka panjang Sistem Informasi Geografi (GIS) mampu mengumpulkan informasi dan data serta menganalisisnya secara spasial yang kemudian menampilkannya dalam bentuk grafik atau peta yang lebih efektif dan lebih mudah untuk dipahami oleh penggunanya [6]. Permasalahan prosedur pemanfaatan aset tanah yang mempunyai beberapa tingkatan merupakan kenadala yang umum di lingkungan pemerintahan. Prosedur dalam pemanfaatan aset tanah di Kabupaten Purbalingga 1) Mengisian blangko yang tersedia di Dinas Perumahan dan Pemukiman. 2) Mengisi form pengajuan permohonan pemanfaatan tanah 3) Membuat surat permohonan pengajuan pemanfaatan aset tanah, 4) Mengirim berkas yang sudah lengkap ke sekretariat daerah. 5) Menunggu surat jawaban Bupati. Jika jawaban permohonan disetujui, dilanjutkan mengambil surat persetujuan Bupati di Dinas Perumahan dan Pemukiman Bidang Pertanahan. Penelitian yang berjudul Aplikasi Sistem Informasi Geografis Untuk Inventarisasi Dan Evaluasi Aset Bangunan Milik Pemerintah Kota Surabaya (Studi Kasus : Surabaya Pusat) [7] dengan hasil penelitian data inventarisasi aset bangunan milik Pemkot Surabaya dan aplikasi sistem informasi geografis berbasis desktop yang memberikan hasil rekap laporan. Penelitian lainya yang membahas tentang sistem informasi geografis adalah tentang persebaran lokasi obyek pariwisata berbasis web dan mobile Android di Dinas Pariwisata Kabupaten Gianyar. Tujuan adalah membantu dinas pariwisata di Kabupaten Gianyar untuk mengelola informasi pariwisata dan membantu wisatawan dalam mencari informasi dari wisatawan. Sistem informasi terdiri dari dua bagian yaitu aplikasi berbasis web dan aplikasi berbasis Android dan dibuat dengan menggunakan PhoneGap. Untuk pengembangan sistemnya menggunakan Metode System Development Life Cycle (SDLC). Hasil penelitian ini adalah sistem informasi geografis yang dapat membantu Dinas Pariwisata Kabupaten Gianyar dalam mengelola obyek-obyek wisata yang ada di Kabupaten Gianyar. Sistem informasi geografis ini dapat mempermudah user/wisatawan dalam mencari informasi obyek dan lokasi wisata di Kabupaten Gianyar. Sistem informasi geografis ini berhasil berjalan di dua platform berbeda yaitu web dan mobile android [8].

Dengan memanfaatkan teknologi berbasis web dan mobile beberapa tingkatan prosedur dapat dilakukan sekali input. Implementasi teknologi Sistem Informasi berpengaruh secara signifikan terhadap manajemen [9] menjadi lebih mudah dan cepat dalam melakukan proses yang ada di Dinas Perumahan dan Pemukiman Bidang Pertanahan.

\section{METODOLOGI}

Subjek penelitian dalam kasus ini adalah Sistem Informasi Geografis Aset Tanah Daerah Kabupaten Purbalingga sebagai media untuk sosialisasi, memudahkan proses pemanfaatn tanah yang di harapkan aset tanah daerah Kapubaten Purbalingga dapat di manfaatkan dengan optimal. Metode yang digunakan oleh peneliti terdiri dari beberapa tahap, diantaranya: 


\subsection{Tahap Analisis Situasi}

Tahap analisis situasi yang berlangsung di objek penelitian disini Ketua dan Anggota 1 melakukan

proses pengambilan data dan observasi yang telah di lakukan pada bulan agustus. Hasil temuantemuan di lapangan dilakukan analisis dan melakukan kesepakatan dengan pihak Dinas Pemukiman dan Perumahan dalam penentuan tujuan, batasan dan lingkup penelitian.

\subsection{Tahap Pelaksaan.}

Tahap pelaksaan pengembangan sistem informasi geografis yang dengan framework Scrum yang terdiri dari, Analisis kebutuhan, Product Backlog dan proses Sprint sampai semua product Backlog sudah selesai Di sini Ketua Peneliti menentunkan product Backlog yang di bagi kedalam 3 Sprint yang diperlukan dalam pembuatan aplikasi Anggota 1 membantu mengawasi setiap hasil Sprint yang di hasilkan oleh programmer dalam pembuatan aplikasi.

\section{SCRUM FRAMEWORK}

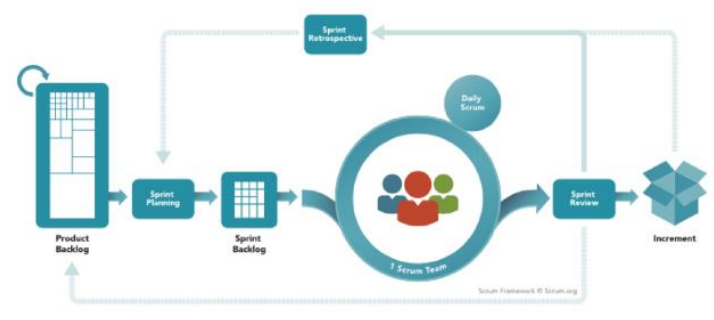

Gambar. 1 Framework Scrum [10]

\subsection{Tahap Ketiga}

Tahapan Implementasi Demonstrasi Model atau Prototipe Sistem dalam lingkungan yang relevan dengan indikator capaian Ketua peneliti dan Anggota 1 melakukan pengawasan dan pemantauan secara bergantian dan berkala untuk menguji hasil kelayakan aplikasi dalam implementasi:

Tabel 1. Indikator capaian

\begin{tabular}{|l|l|l|}
\hline No & Indikator & Aspek \\
\hline 1. & Sistem & Admin dari dinas \\
& informasi & perumahan dan dapat \\
& geografis & pemukiman \\
& berjalan & mengoperasikan dan \\
& dengan lancar & sistem dengan lancar. \\
& dan & Pengguna dapat \\
& terkendalali. & $\begin{array}{l}\text { menjalankan aplikasi } \\
\text { tanpa terkendala }\end{array}$ \\
\hline
\end{tabular}

\begin{tabular}{|l|l|l|}
\hline 2. & Informasi & Pengguna bisa \\
tentang aset & menemukan data aset \\
tanah daerah & tanah yang bisa \\
dapat diakses & dimanfaatkan oleh \\
dengan & masyarakat. \\
mudah. & & \\
\hline
\end{tabular}

\subsection{Tahap Dokumentasi.}

Tahap keempat yaitu tahap pengumpulan dokumentasi hasil penelitian dan penyusunan laporan dari penelitian Ketua mengumpulkan dokumentasi dalam pengembangan aplikasi berupa product backlog, hasil sprint dan hasil implementasi. Anggota 1 melakukan pengumpulan dokumen-dokumen lain yang dibutuhkan dalam pelaporan.

\section{HASIL DAN PEMBAHASAN}

\subsection{Product Backlog}

Sistem Informasi ini bertujuan untuk membantu Dinas Perumahan dan Permukiman Kabupaten Purbalingga dalam memanajemen pengelolaan aset milik daerah atau tanah milik daerah. Sistem ini dilengkap menggunakan GIS (Geographic Information System) yang berfungsi untuk memetakan lokasi tanah milik daerah dengan memanfaatkan peta virtual. Sehingga pemantauan lokasi dan pengelolaan tanah milik daerah lebih terkontrol dengan baik.

Kelengkapan data yang dibutuhkan guna pengembangan Sistem informasi yaitu sebagai berikut:

1. Data admin adalah data pengguna dari pihak Dinas Perumahan dan Permukiman Kabupaten Purbalingga. Admin ini yang nanti akan mengelola berjalannya sistem.

2. Data pengguna merupakan data pengguna umum yang menggunakan website secara universal.

3. Data tanah milik daerah merupakan data aset yang berupa tanah milik daerah. Data ini menunjukan informasi lengkap mengenai aset yang ada pada sistem ini yang nantinya akan dikelola oleh admin dan dilihat oleh pengguna umum.

4. Data kecamatan adalah data mengenai kecamatan mana saja yang terkait dengan informasi lokasi tanah. Data ini menjadi informasi pelengkap mengenai tanah milik daerah.

5. Data kelurahan adalah data mengenai kelurahan mana saja yang terkait dengan informasi lokasi tanah. Data ini juga menjadi informasi pelengkap mengenai tanah milik daerah. 
6. Data pemanfaatan tanah merupakan data yang berhubungan dengan tanah milik daerah yang sedang digunakan maupun disewa.

7. Data ini merupakan data yang digunakan untuk ditujukan kepada pengguna umum mengenai tata cara yang dilakukan jika hendak mengajukan permohonan pemanfaatan tanah.

8. Alur yang digunakan agar berjalannya sistem dengan baik dan terstruktur. Untuk admin, alur yang digunakan yaitu sebagai berikut:

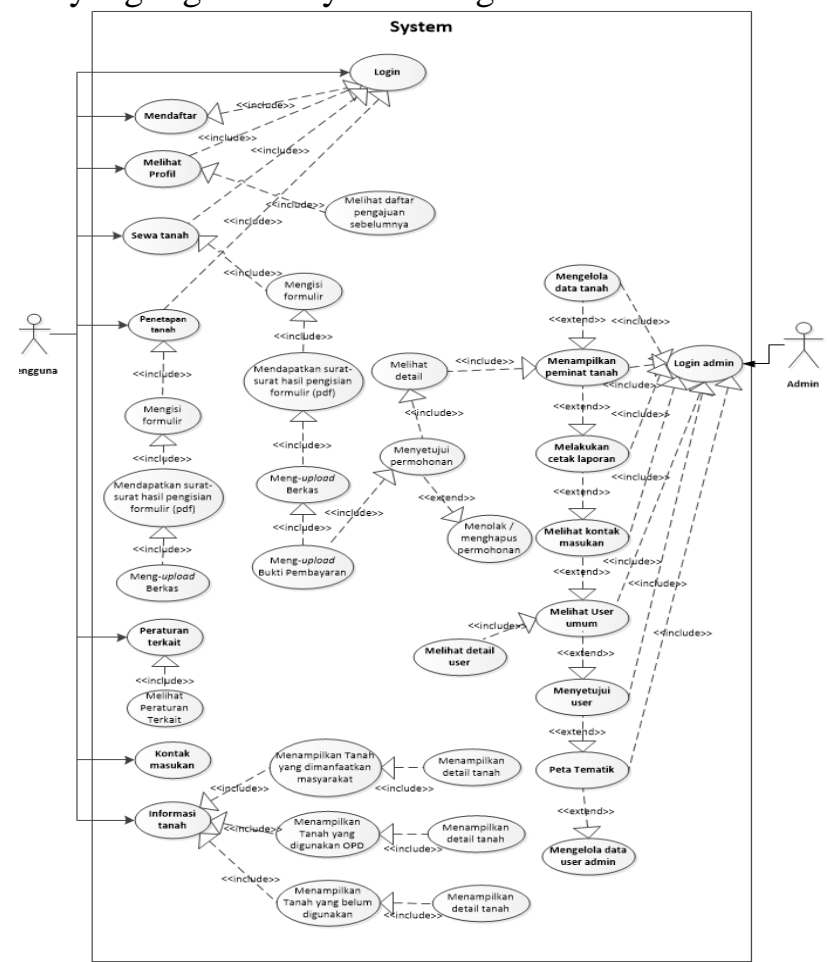

Gambar 2 Usecase Design Activity Diagram Sewa tanah masyarakat

Activity Diagram Penetapan tanah OPD Menjelaskan aktivitas masyarakat dalam melakukan penyewaan tanah pada system informasi. Hal pertama setelah melakukan aktivitas login yaitu user dapat mengakses URL utama website sehingga sistem akan menampilkan halaman utama. Lalu pada halaman utama, user dapat mengakses menu sewa tanah dan sistem akan menampilkan halaman tata cara sewa tanah. User dapat melanjutkan ke langkah selanjutnya. Tetapi terdapat validasi. Jika user berstatus Organisasi Perangkat Daerah (OPD) yang mengaksesnya maka akan ditolak dan menampilkan pesan tidak bisa melanjutkan. Namun user benar berstatus masyarakat maka sistem akan memperbolehkan mengakses langkah selanjutnya. Langkah selanjutnya yaitu pengisian formulir penyewaan tanah. User diharuskan meng-input data yang diperlukan. Setelah itu, proses selanjutnya yaitu menampilkan halaman unduh berkas surat pernyataan dan berkas yang diperlukan dari hasil pengisian formulir. User dapat mengunduhnya pada halaman tersebut dan melanjutkannya ke halaman upload berkas.

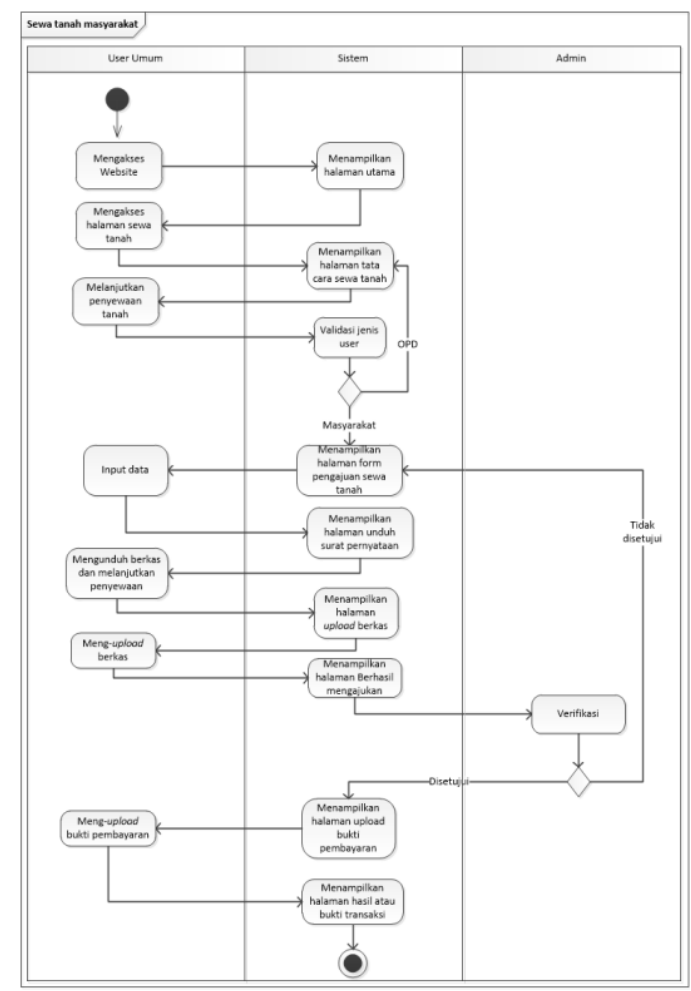

Gambar 3. Activity Diagram

Pada halaman upload berkas, user dapat mengunggah berkas-berkas yang diperlukan. Jika sudah mengunggah berkas maka sistem akan menampilkan pesan berhasil mengajukan. Pada saat itu admin dapat memilih dan memverifikasi untuk menyetujui atau menghapus pengajuan yang dilakukan oleh user. Jika disetujui, maka sistem akan memperbolehkan user untuk melanjutkan ke halaman upload pembayaran sesuai dengan ketentuan. User pada halaman ini dapat mengunggah bukti pembayaran jika syarat-syarat sudah dipenuhi. Jika admin menolak atau menghapus pengajuan maka user tidak dapat melanjutkan penyewaan dan bisa mengulang ke proses pengisian form penyewaan.

Menjelaskan aktivitas user yang berstatus OPD dalam melakukan penetapan/penggunaan tanah pada website. Hal pertama setelah melakukan aktivitas login yaitu user dapat mengakses URL utama website sehingga sistem akan menampilkan halaman utama. Lalu pada halaman utama, user dapat mengakses menu penetapan tanah untuk OPD dan sistem akan menampilkan halaman tata penggunaan tanah. User dapat melanjutkan ke langkah selanjutnya. Tetapi 
terdapat validasi. Jika user berstatus masyarakat yang mengaksesnya maka akan ditolak dan menampilkan pesan tidak bisa melanjutkan. Namun user benar berstatus OPD maka sistem akan memperbolehkan mengakses langkah selanjutnya.

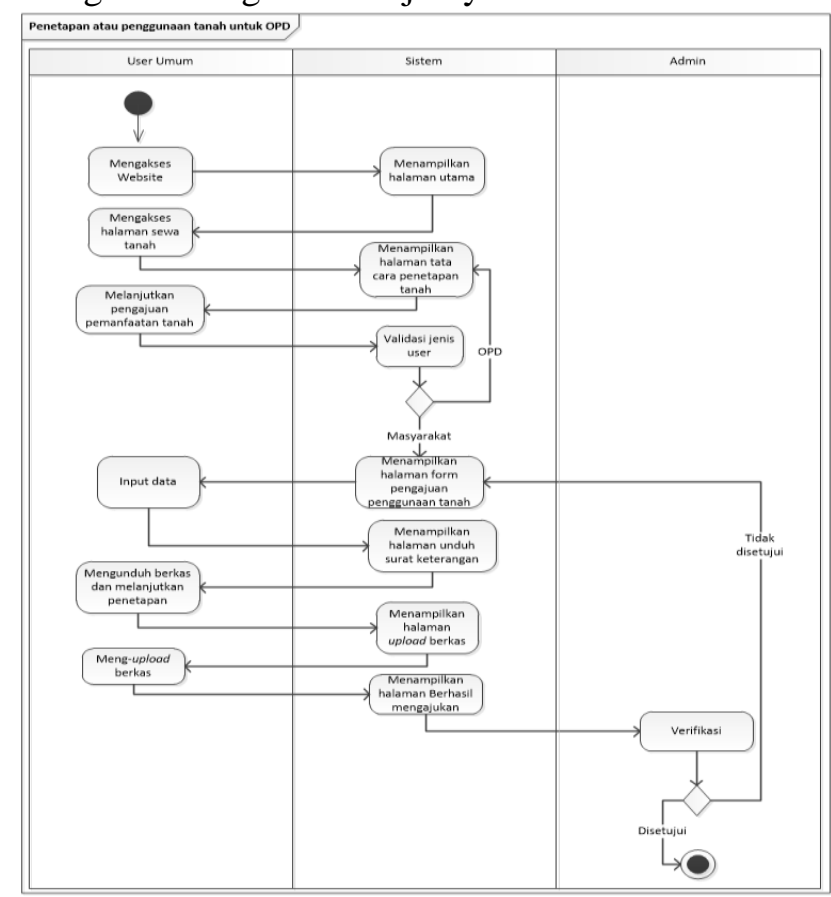

Gambar 4. Activity Diagram Penetapan tanah OPD Langkah selanjutnya yaitu pengisian formulir pengajuan penetapan tanah. User diharuskan menginput data yang diperlukan. Setelah itu, proses selanjutnya yaitu menampilkan halaman unduh berkas surat keterangan dan berkas yang diperlukan dari hasil pengisian formulir. User dapat mengunduhnya pada halaman tersebut dan melanjutkannya ke halaman upload berkas. Pada halaman upload berkas, user dapat mengunggah berkas-berkas yang diperlukan. Jika sudah mengunggah berkas maka sistem akan menampilkan pesan berhasil mengajukan. Pada saat itu admin dapat memilih dan memverifikasi untuk menyetujui atau menghapus pengajuan yang dilakukan oleh user. Jika disetujui, maka user tinggal menunggu informasi lebih lanjut dari pihak Dinrumkim. Jika admin menolak atau menghapus pengajuan maka user tidak dapat melanjutkan penyewaan dan bisa mengulang ke proses pengisian form pengajuan.

\subsection{Class Diagram}

Class diagram pada sistem. Mulai dari class masuk atau login. Class login berasosiasi dengan arah class menu utama sehingga class login dan class menu utama saling berkaitan. Class menu utama berasosiasi dengan class lain seperti menu hak akses, tanah, peminat tanah, kontak, kecamatan, kelurahan, user, user admin, dan layer map. Menu utama merupakan class yang membutuh-kan class lain. Sehingga tanpa adanya class tersebut maka menu utama tidak akan berfungsi. Maka dari itu diperlukan asosiasi dengan class yang mendukung agar bisa berfungsi dengan baik.

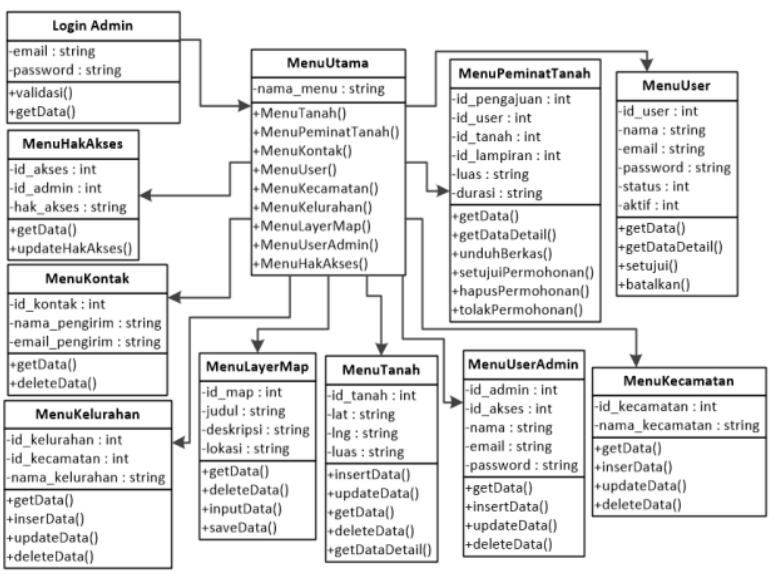

\section{Gambar 5. Class Diagram}

GIS dalam sistem informasi guna memperlihatkan bentuk dari aset tanah daerah dan juga titik lokasi aset tanah tersebut berada bentuk desain dari GIS aset tanah daerah terbentuk dari bebrapa layer di dalam peta. Drawing tools canvas menjadi penyimpanan aset tanah dengan tampilan base map canvas di ambil dari API Google Maps [11].

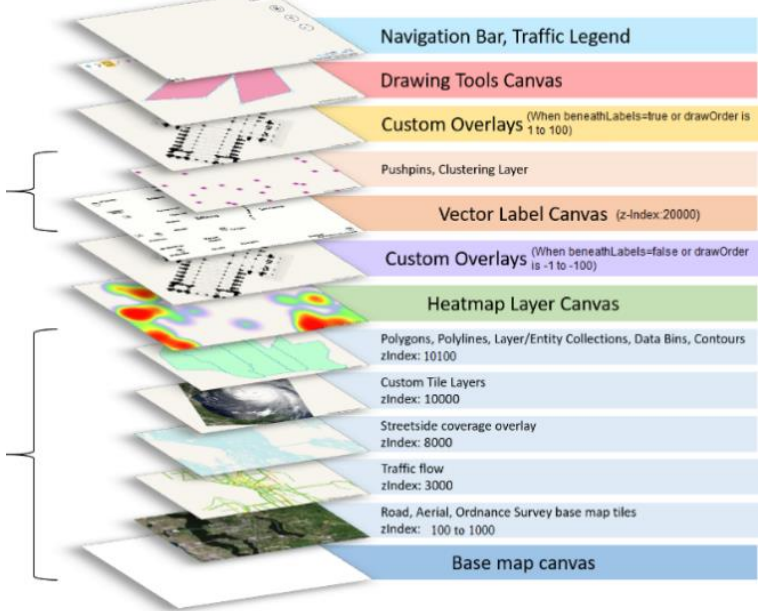

Gambar 6. Maps Layer [12]

\subsection{Hasil Sprint}

Sprint yang dilaksanakan berdasarkan dari product backlog menghasilkan website dan aplikasi android dengan tujuan untuk memudahkan proses penyewaan aset tanah daerah dan memberikan pengetahuan kepada khalayak umum dengan 
memberikan informasi yang dapat diakses secara terbuka oleh masyarakat.
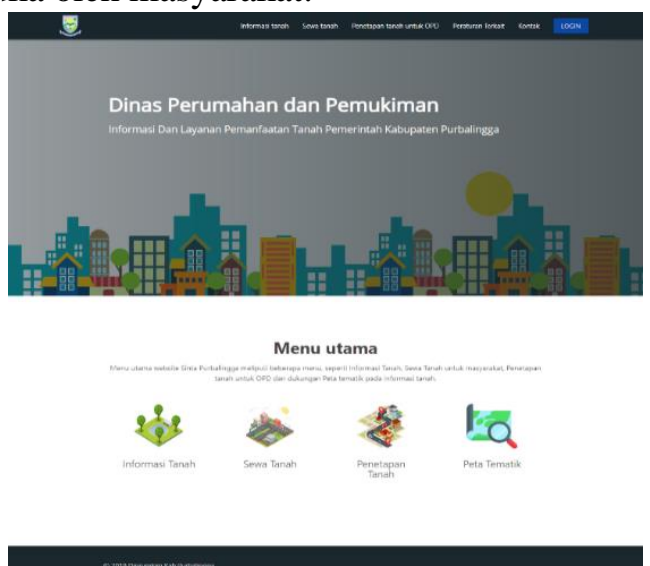
Gambar 7. Tampilan halaman utama pengguna

Tampilan halaman utama saat pengguna pertama kali mengakses website. Pada halaman ini akan ditampilkan menu utama yang ada pada website.

Menampilkan hasil halaman website untuk mengelola layer map pada kanvas map.

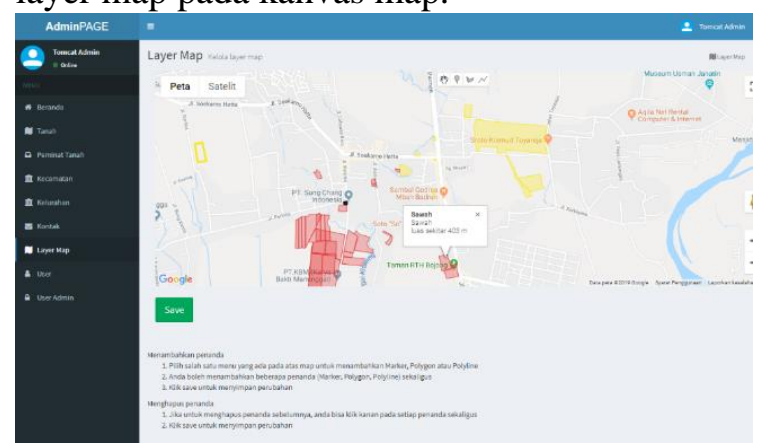

Gambar 8. Hasil penerapan fitur marker, polygon dan polyline.

GIS Aset tanah daerah yang dapat penerapan fitur marker, polygon dan polyline akan di implementasi di dalam pendataan tanah, proses tampilan di dalam halaman utama dan proses tampilan di dalam proses sewa aset tanah daerah.

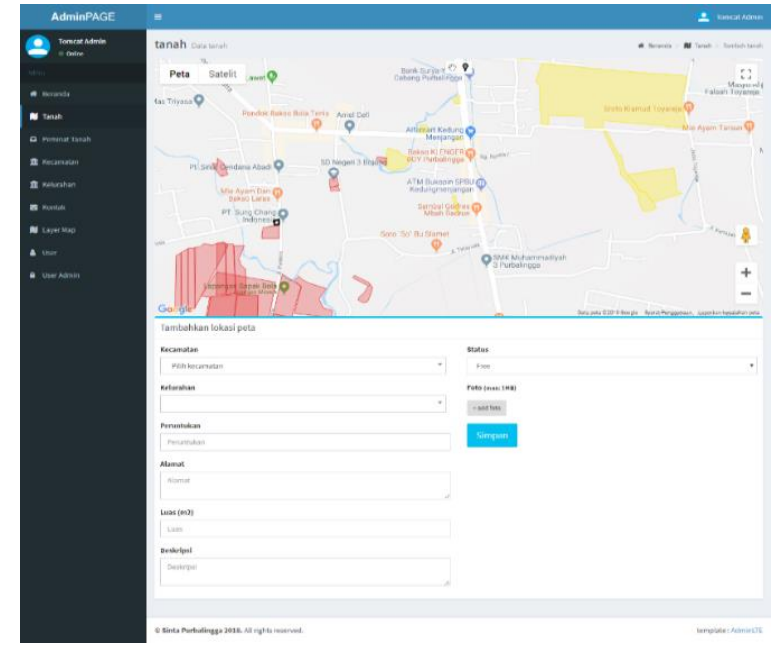

Gambar 9. Tampilan halaman tambah data tanah

Tampilan halaman tambah data tanah di gunakan oleh admin setelah mengakses tombol tambah tanah pada halaman data tanah. Pada halaman ini akan ditampilkan kolom-kolom isian untuk menambahkan data tanah.

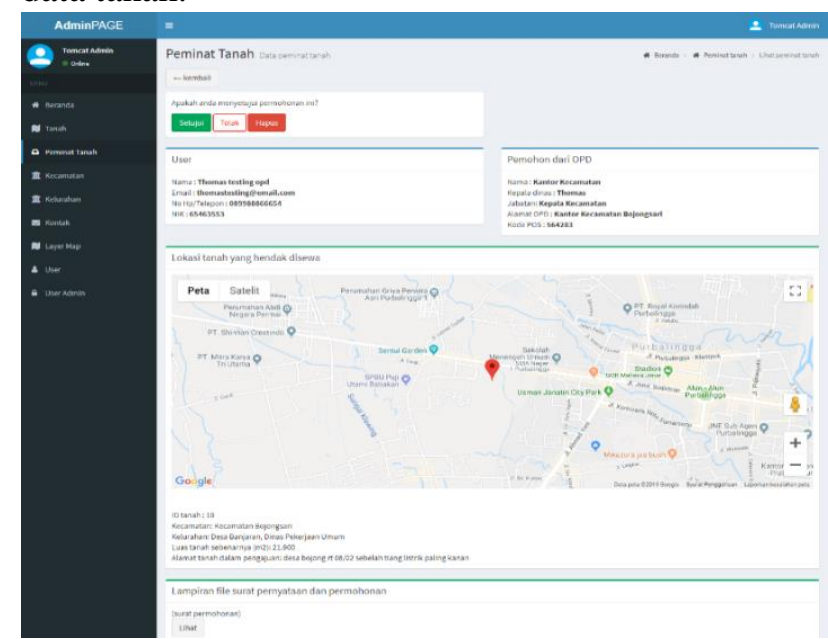

Gambar 10. Tampilan halaman peminat tanah

Tampilan halaman pada data detail dari peminat yang mengajukan permohonan pemanfaatan tanah. Halaman ini ditampilkan setelah admin mengakses link lihat pada setiap data yang ditampilkan. Pada halaman ini, admin dapat melihat berkas yang dikirimkan. Selain itu juga dapat menyetujui, menolak, menghapus atau membatalkan permohonan. 

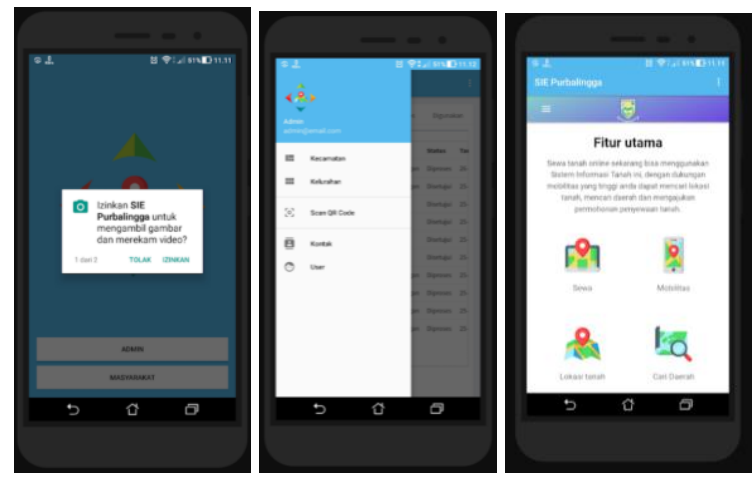

Gambar 10. Tampilan versi mobile

Aplikasi Mobile yang dihasilkan guna memudahkan proses melihat lokasi tanah yang ada di dalam system dengan penggabungan data GPS yang ada di smartphone sehingga dapat menemukan lokasi aset tanah pemerintah daerah yang dapat di sewa.

\section{SIMPULAN DAN SARAN}

Kesimpulan dari penelitian ini adalah terbentuknya sistem informasi penyewaan aset tanah daerah berbasis website dan android. Metode Scrum yang digunakan dalam proses pembuatan menghasilkan penyelesaian sistem dengan sesuai. Sistem informasi aset tanah daerah membantu pihak Dinas Perumahan dan Pemukiman dalam memberikan informasi aset tanah daerah yang dapat disewakan dengan memanfaatkan GIS untuk membantu melihat posisi aset tanah. Saran untuk penelitian selanjutnya adalah sistem dilengkapi dengan pelaporan penyalahgunaan aset tanah daerah.

\section{UCAPAN TERIMA KASIH}

Peneliti Pengucapkan terima kasih kepada semua elemen yang mendukung penelitian ini: Kepada Dikti yang telah memberi pendanaan penelitian, Kepada Universitas AMIKOM Purwokerto atas dukungan dan bimbinganya dalam melaksanakan penelitian. Kepada Dinas Prumahan dan Pemukian sebagai objek penelitian yang memberikan data dan kerjasama dalam melaksanakan penelitian.

\section{REFERENSI}

[1] S. S. \&. U. K. Mateen, "A Development of Hybrid Framework for E-Government," International Journal of Management, IT \& Engineering Vol. 7 Issue 2, pp. 88- 101., 2017.
[2] Rais, "Sistem Informasi Geografi: Pengertian dan Aplikasinya," 1410 2018. [Online].

Available:

http://s3.amazonaws.com/academia.edu.docume nts/44545640/02_-

_STMIK_AMIKOM_Yogyakarta_Sistem_Infor masi_Geografi_Pengertian_dan_Pemanf aatannya.pdf?AWSAccessKeyId=AKIAIWOW YYGZY53UL3A\&Expires=1500382179.

[3] United Nations, "United Nations E-Government Survey 2018," United Nations, New York, 2018.

[4] R. \&. F. R. Apriyanti, "Pemanfaatan Sistem Informasi Geografis (SIG) dalam Penentuan Lokasi Perumahan di Kota Depok," in Prosiding Seminar Ilmiah Nasional Komputer dan Sistem Intelijen, Depok, 2014.

[5] A. P. \&. S. Saido, "Pemetaan Tanah Aset Pemerintah Kota Studi Kasus: Tanah Aset Pemerintah Kota Probolinggo.," in Konferensi Nasional Teknik Sipil 7 (KoNTekS 7), Surakarta, 2013.

[6] H. \&. R. Purnaweni, "Pemanfaatan Sistem Informasi Geografi dalam Pengembangan Pariwisata," in Proceeding Biology Education Conference Volume 14, Nomor 1, Semarang, 2017.

[7] M. \&. A. A. S. Taufik, "Aplikasi Sistem Iinformasi Geografis untuk Inventarisasi dan Evaluasi Aset Bangunan Milik Pemerintah Kota Surabaya (Studi Kasus : Surabaya Pusat)," GEOID Vol. 12 No. 01, , pp. 43-47, 2016.

[8] I. B. \&. E. R. Adnyana, " Rancang Bangun Sistem Informasi Geografis Persebaran Lokasi Obyek Pariwisata Berbasis Web dan Mobile Android (Studi Kasus Di Dinas Pariwisata Kabupaten Gianyar," Jurnal Teknologi Informasi dan Komunikasi, pp. 1-9, 2014.

[9] I. Azhar, "Pengaruh Sistem Informasi terhadap Manajemen Aset pada Pemerintah Kota Banda Aceh.," JURNAL PENELITIAN EKONOMI AKUNTANSI (JENSI), pp. 150-160, 2017.

[10] K. Schwaber and J. Sutherland, "Scrum Guide," 118 2018. [Online]. Available: http://www.scrum.org.

[11] A. Shodiq, " Tutorial Dasar Pemrograman Google Maps API," 129 2018. [Online]. Available: https://developers.google.com/maps/documentat ion/javascript/maptypes. 
[12] Microsoft, "zIndexing in Bing Maps V8," https://docs.microsoft.com, 282 2018. [Online]. Available: https://docs.microsoft.com/enus/bingmaps/v8-web-control/articles/zindexingin-bing-maps-v8. [Accessed 186 2018]. 